\title{
Inequalities, Vulnerabilities, and Discrimination in the Context of COVID-19
}

\author{
Daniela Roventa - Frumusani and Valentina Marinescu \\ The Faculty of Sociology and Social Work, University of Bucharest, Romania
}

Неравенства, уязвимости и дискриминация в контекста на COVID-19

Даниела Ровента - Фрумусани и Валентина Маринеску

Факултет по социология и социална работа към Букурещки университет, Румъния

\section{Author Note}

Daniela Roventa-Frumusani

https://orcid.org/0000-0001-7878-7147

Valentina Marinescu (D) https://orcid.org/ 0000-0002-9882-5902

The authors have no known conflict of interest to disclose.

Correspondence concerning this article should be addressed to Daniela RoventaFrumusani. Email: danifrumusani@yahoo.com

\section{Бележки за авторите}

Даниела Ровента-Фрумусани https://orcid.org/0000-0001-7878-7147

Валентина Маринеску https://orcid.org/ 0000-0002-9882-5902

Авторите нямат конфликт на интереси.

Кореспонденцията, свързана с тази статия, трябва да бъде адресирана до Даниела Ровента-Фрумусани danifrumusani@yahoo.com 
Among the most pressing political issues of our age are inequality, exclusion, and discrimination. Unfortunately, they are on the rise in the context of COVID-19. There are several dimensions involved in this approach, and the most important one is that of "exclusions."

According to Beall and Piron (2004), exclusion from social, political, and economic institutions results from a complex and dynamic set of processes and relationships that prevent individuals or groups from accessing resources, participating in society, and asserting their rights. There is a process of exclusion and agency involved - the behavior of particular agents and institutions leads to the exclusion of certain groups. Indeed some include this as part of the definition of social exclusion:

"Social exclusion is the process through which individuals or groups are wholly or partially excluded from full participation in the society in which they live" (de Haan \& Maxwell, 1998).

"Social exclusion occurs when the institutions that allocate resources and assign value to operate in ways that systematically deny some groups the resources and recognition that would allow them to participate fully in social life" (Zeitlyn, 2004).

The identification and characteristics of excluded groups are necessarily society dependent. Most socially excluded groups are deprived in multiple ways. They have different characteristics (other than their deprivations) from others in the society they live in, which enables them to be identified as a group and discriminated against. In an interesting article, Hoff and Pandey (2006) showed that a discriminatory regime affects the structure of opportunities open to different social groups and the status and social meanings assigned to those groups-their social identities. If these identities influence behavior, then even after opportunities have been equalized across groups, the discriminatory regime will have persistent effects.

Social vulnerability taps on a broad range of susceptibilities at the individual and community level: lack of access to resources and lifelines, insufficient information and wellbeing; and certain beliefs and customs (de Oliveira Mendes, 2009). Also, some indicators measuring deficiencies in infrastructure make people with compromised statuses more socially vulnerable to social, economic, and environmental hazards (Hewitt, 2014). On the other hand, social vulnerability is context-dependent and is often associated with the degree of 
exposure to extreme events and with the preparedness and resilience of individuals and social groups (Wisner et al., 1993).

Is the current COVID-19 pandemic increasing or decreasing inequalities, vulnerabilities, and discrimination in present societies? How steep is the social gradient of the COVID-19 impact? What will be the long-run impact of COVID-19 pandemic on markets, policies, and institutions? How to evaluate the combined effects of the pandemic on inequalities, vulnerabilities, and discrimination? In our opinion, the answers to the questions mentioned above could increase the understanding of inequality, vulnerability, and discrimination in present days societies.

The French economist Frédéric Bastiat (Bastiat and DeVos, 2020) stressed that every policy "produces not only one effect but a series of effects." The immediate and intended effects are what he calls "the seen," while the indirect, unintended consequences are "the unseen." "The seen" usually gets all the attention, while "the unseen" often goes neglected.

In the COVID-19 pandemic, "the seen" are the virus victims and those who hopefully avoid spreading or catching the disease because of the lockdowns. They are, without a doubt, worthy of our care and attention.

But we also must not ignore "the unseen": the millions of human beings who, as a result of the lockdowns, have become victims of domestic violence, drug overdoses, depression, suicide, and more.

"The lives ruined or snuffed out by the lockdowns deserve better than that. They deserve to be seen" (Miltimore, 2020).

The unintended and unforeseen consequences of the COVID-19 lockdowns have been severe: mass unemployment, increased drug overdoses and suicides, and widespread social unrest are only a few of them.

As the Inter-American Commission on Human Rights and the United Nations have emphasized, countries must incorporate a gender perspective in their responses to the COVID-19 crisis. Several countries and nongovernmental organizations (NGOs) have already taken innovative steps in this direction. New campaigns also use social media to spread awareness of resources available to survivors, including hotlines, text message-based reporting, and mobile applications.

Domestic violence in extreme individual and collective forms (genocide, femicide, homicide) was a global pandemic long before the COVID-19 outbreak. According to the 
United Nations, 243 million women and girls between fifteen and forty-nine years worldwide were subjected to sexual or physical violence by an intimate partner in the last twelve months.

The studies in the special issue of "Postmodernism Problems" focus upon the axes mentioned above and, in addition, they approach others from the wide range of the old and new inequalities, vulnerabilities, and discrimination brought by COVID-19 in contemporary societies (Lombard \& McMillan, 2018, p, 3).

Thus, the article "Citizens facing COVID-19: Inequalities and Vulnerabilities of the Working Class (The world before covid-19)" by Carl E. D. Pierre relies on recent studies to describe the hardship of working-class people during the COVID-19 crisis, their vulnerabilities, and how social inequalities play a major role in their exposure to the virus and its more severe and potentially deadly expressions. The author shows how existing inequalities before the pandemic and public policy create the sanitary, financial, and economic disaster we are facing now. According to Carl E. D. Pierre, it is crucial to understand the pandemic's impacts on blue-collar workers and state-sponsored measures to fight against it. The paper also shows the need for further research on working-class issues such as their resilience to financial and sanitary hardship.

"The Violence Against Women during the COVID-19 Pandemics" by Diana Stoica assessed from the beginning that one of the biggest crises of the modern world - the COVID19 pandemic - brought with itself new measures to be implemented all around the world. The lockdowns imposed to prevent the spread of the virus affected numerous aspects of everyday life and mainly created a hidden pandemic indoors. Diana Stoica pointed out that her paper's purpose was to underline the impact of the COVID-19 pandemic in what concerns the violence against women (VAW). Although it might seem early for estimating the damages produced in this area of study, there can be envisaged many statistics, a lot of system weaknesses, and possible solutions to help the victims. Her article resumed the whole chaos installed on the Globe behind the closed doors, in the family - the most intimate place, where the joy and the love should dominate.

In "The Guardian's Coverage of "Me Too" and "Time's Up" Movements," Tsvetelina Dzhambazova analyzed the media texts about the new social justice movements "Me Too" and "Time's Up." The analyzed materials were published on The Guardian's website (theguardian.com) between October $5^{\text {th }}, 2017$, and December 31 $1^{\text {st }}, 2018$ (thus marking both campaigns' first anniversary). The article aimed to study the methods through which both 
initiatives are presented in the British medium. The article's important tasks were to see if this website's authors express an attitude towards the movementsTheharticle's important task is any connection between these campaigns and the existing calls for changes in the check roles of sexes in modern society. The Guardian's journalists actively present attempts to eliminate sexual violence and simultaneously express a largely positive attitude toward those activists to eliminate forts to eradicate gender discrimination. The public is mostly characterized by a significant generic variety, while calls for changes in men and women's social roles can often be found in the analyzed texts.

Simona Rodat, in the paper "Coping with Stigma and Destigmatizing Intervention Strategies: An Analytical Framework," addressed the stigmatization process, outlining the meaning of the social stigma and the different types of stigmata, focusing further on how stigmatized people cope with stigma and on the main intervention strategies that can be used for destigmatization. A social stigma is an undesirable characteristic or an unfavorable element, along with any generalization or attribution of further characteristics that can lower or humiliate the individual. The characteristic itself, but a negative meaning in the social and cultural context, makes the person concerned a stigma bearer. Stigmatization describes how actual or potential negative characteristics are ascribed to a person, and thus this person is assigned to a certain socially disregarded group. At the same time, stigmatization involves the association to the person concerned with the prejudices and stereotypes connected to the assigned devaluating characteristic and the experience of varied forms of discrimination. In order to avoid the consequences of their social stigma, the people concerned to develop in diverse social situations in different ways to cope with their stigmatization. Among these, correction, avoidance or defensive attitude, inner distance, compensation, alternative relationships, external assignment, and hostile bravado are highlighted and discussed in the paper. Destigmatization, as a reverse process to stigmatization, can be targeted through various intervention strategies. The article addressed the most frequently used destigmatizing intervention strategies, namely protest, education, and contact, emphasizing their strengths, especially of the last two, and arguing that, depending on the type of stigma and the social context, a mixture of intervention strategies is more effective, and therefore desirable.

In the paper "From complexity to fear and optimism in everyday life with COVID-19" Plamen Atanasov showed that the COVID-19 pandemic of 2020 developed into a crisis of civilizational type. The interactions within society are more complicated: what dominates is 
high complexity, prominent confusion, low social trust levels, and permanent fear. This leads to conspiracy theories, as well as behavioral infections ranging from depressions to aggression; while simultaneously, it creates the need for hope and optimism. The paper aimed to show that overcoming the social estrangement and balancing fear with optimism and hope is essential for the future of social reality. The paper used existing scientific developments from the fields of psychology, sociology, and the media, in addition to publicly available articles from the mass media. Based on them, the author defined the problem set out as the consequence of unresolved matters around the neoliberalism that infiltrates the social interactions, the fear and the conspiracy theories, and the poorly understood need for optimism and hope. The scientific inquiry focused on these problems entering the mass media, where the situation is unusual, as far as the fear of COVID-19 is concerned. In these circumstances, Plamen Atanasov pointed out that it is imperative that both society and the media evaluate their attitude towards neoliberal policies and find their balance between fear and the need for hope.

David A. Hernández-Ontiveros and Diego-Oswaldo Camacho-Vega in the article "Academic success between disabling hearing loss and hearing students in Upper-Secondary: An inclusive Classroom" consider that the academic performance between disabling hearing loss (DHL) and hearing students is unclear when considering students in the same classroom. Their study's main objective was to identify significant differences in grade by semester between DHL students who study in the same classroom supported by sign language interprets. Second, the study aimed to identify what school subjects show significant differences between DHL and hearing students. $N=35$ upper-secondary students from a Mexican school with an inclusive educational methodology (deaf and hearings share the same classroom supported by an interpreter) participated in the study $(M=17 ; S D=2.2), n=21$ disabling hearing loss students (52\% males) and $n=14$ hearing students were followed during three years (six semesters). The first step was to obtain the previous grade earned in their lowsecondary studies. Second, was got the overall grade by semester identifying grades by subject and comparing results between groups. Results indicated significant differences in academic performance, showing higher mastery for DHL students in the fourth and fifth semesters, particularly in computer-logical subjects as well as social subjects. In conclusion, this research provides evidence that supports the success of an inclusive methodology where DHL and hearing students share the same instructional design supported by a sign language 
interpreter. Additionally, DHL students performed better in the computer-logical subjects, an essential skill daily but even more in the current COVID -19 crisis and social subject, an important factor suggested by prior evidence.

"Exposure to and Self-Perceptions of the Risk of Discrimination and Social Exclusion in Access to Public Goods, Media, Healthcare and Employment" by Svetlana D. Hristova and Valentina Milenkova examined the dimensions of social exclusion and the elements of selfperception of discrimination in access to public goods, employment, and to the media, which is juxtaposed with the priorities of the Bulgarian National Roma Integration Strategy (NRIS). The findings were based on the "National representative sociological survey for identifying and elaborating profiles of groups and communities most affected by the risk of discrimination, such as the Roma" carried out in 2017 with a sample of 3,600 individuals aged 18 or over. The paper shows the contrast between a variety of quality indicators and the priorities of the NRIS. Based on the data obtained, the risk of discrimination among the Roma and other ethnic groups in Bulgaria is tracked in a comparative manner in major public spheres. The survey results demonstrated that the most vulnerable people in the country are those without health insurance, residing in hard-to-reach settlements, low-qualified and unemployed individuals, people with disabilities, multi-member families, and single parents; these categories indisputably include a solid share of Roma. Nevertheless, as the results showed, not all Roma and arguably not only Roma were the most disadvantaged and marginalized individuals in Bulgarian society. The article's outcomes were related to profiling the groups at risk, allowing critical linkages between the empirical data and ways of improving equal opportunities and non-discrimination policies. In the end, the authors stressed for the identification of adequate measures and a balanced approach to political engagement with the planning process in the coming years.

Antonio Amuza in the paper "The need for authenticity in opinion formation," pointed out the fact that the need for authenticity is a latent manifesto of Romanians who seem overwhelmed by a constant wave of inauthenticity, prejudices, and stereotypes in an environment that makes it more difficult for us to adhere to a genuine development not only as individuals but also as a society. Public opinion reveals itself under the impact of the desired authenticity in order to cope with galloping globalism, which turns us into bystanders of our own lives. More specifically, in a world where we have become accustomed to our ideas being very aesthetically packed, the characteristics of the products for which we show a 
certain interest, the quality of the services we want and the values we so ardently adhere to, the need to be sure that we receive exactly what we have been mentally longing for becomes a purpose in itself. Thus, the more common and plentiful the values, assumed the author, people are exposed to, along with the risk that they may be prebuilt, the greater the possibility for people to develop the need for a guarantee of compliance with the promises made by these values - a need for authenticity.

\section{References}

DeVos, B. (ed). (2020). The best of Frederic Bastiat. American Institute for Economic Research. Great Barrington, MA. https://www.aier.org/product/best-of-frederic-bastiat/

Beall, J., and L.H. Piron. (2004). DFID Social Exclusion Review. LSE/ODI https://www.odi.org/sites/odi.org.uk/files/odi-assets/publications-opinionfiles/2301.pdf

de Haan, A. \& S. Maxwell (1998). Poverty and social exclusion in North and South. IDS Bulletin, 29(1). https://doi.org/10.1111/j.1759-5436.1998.mp29001001.x

de Oliveira Mendes, J. M. (2009). Social vulnerability indexes as planning tools: beyond the preparedness paradigm. Journal of Risk Research, 12(1), 43-58. https://doi.org/10.1080/13669870802447962

Hoff, K., \& Pandey, P. (2006). Discrimination, social identity, and durable inequalities. American Economic Review, 96(2), 206-211.

Lombard, N. (2018). Introduction to gender and violence. In L. Sarah (ed), The Routledge Handbook of Gender and Violence, (pp.1-13). Routledge.

Miltimore, J. (2020). Domestic violence more than doubled under lockdowns. New Study Finds.

https://fee.org/articles/domestic-violence-more-than-doubled-under-lockdowns-new$\underline{\text { study-finds }}$

Wisner, B., Luce, H. (1993). Disaster vulnerability: scale, power, and daily life. Geo J. 20(1993), 127-140. https://doi.org/10.1007/BF00808129

Zeitlyn, D. (2004). The gift of the gab. Anthropology and conversation analysis. Anthropos, 99(2), 451-468. https://kar.kent.ac.uk/10722/ 